Environment Conservation Journal 15(3)133-135, 2014

ISSN 0972-3099 (Print) 2278-5124 (Online)

Abstracted and Indexed

\title{
Effects of irrigation and phosphorous levels on yield attributes and yield of chickpea (Cicer arietinum L.)
}

\author{
Angad Prasad ${ }^{1}$ and R.K. Upadhyay ${ }^{2} \bowtie$ \\ Received:15.06.2014 \\ Revised:11.08.2014
}

Accepted:21.08.2014

\begin{abstract}
A field experiment entitled "Effect of irrigation and phosphorous levels on yield attributes and yield of chickpea (Cicer arietinum L.)" conducted at the Agronomy Research Farm of Narendra Deva University of Agriculture \& Technology, Kumarganj, Faizabad during two consecutive rabi seasons of 2004-05 and 2005-06. The results revealed that, the application of two irrigations, one each at branching and pod formation stage in conjunction with $60 \mathrm{Kg} \mathrm{P}_{2} \mathrm{O}_{5} / \mathrm{ha}$ provided highest yield and yield contributing characters of chickpea as compared to other treatments.
\end{abstract}

Keywords: Chickpea, irrigation, nutrient management, phosphorous

\section{Introduction}

Chickpea (Cicer arietinum L.) is an important coolseason food legume having extensive geographical distribution. The world cicer is derived from the Greek "Kiros" referring to well known Roma family Cicero. Arietinum is derived from the Latin word "aries" meaning ram which refers to ram's head shape of the kabuli chickpea. Chickpea is knowan by different names in various countriessuch as gram, chana, bengalgram, pois, hoos, hommos, grao-de-beco and garbanzo. Chickpea mostly consumed in the form of processed whole seed or dal. It is used in preparing of variety of snacks, sweets, and condiments. Fresh green seed are also consumed as green vegetables. In India, chickpea occupying $8.81 \mathrm{mha}$ area with production of $6.68 \mathrm{mt}$ accounts 65 and 68 per cent of total global area and production, respectively (Ali et al. 2003). Globally, chickpea is cultivated on about 10.4 million hectares area adding 8.57 million tons of grain to the global basket, with an average productivity $826 \mathrm{~kg} / \mathrm{ha}$ (Ali \& Kumar, 2005). Major chickpea producing states Madhya Pradesh, Rajsthan, U.P.,Maharshtra, Karnataka, and Gujarat which together, accounts for more than 85 per cent of area and 96 per cent of the production

\section{Author's Address}

${ }^{1}$ Department of Agronomy, Narendra Deva University of Agriculture \& Technology, Kumarganj, Faizabad (U.P.), India

${ }^{2}$ Division of Agronomy \& Soil Science, CSIR-Central Institute of Medicinal \& Aromatic Plants, Research Centre, Pantnagar, PO- Dairy Farm Nagla, U.S. Nagar (Uttarakhand), India E-mail:dr.rku@rediffmail.com
Approximately $60 \%$ of the total pulse is contributed by rabi pulse. Chickpea is predominantly grown under rainfed condition during winter season in country. Depending upon the location and availability of soil moisture, sowing time is extended from second fortnight of September to last week of October. The most important abiotic stress is soil moisture stress at various stages of crop growth and to a lesser extents, salinity. Occasionally, water logging and deficiency of mineral nutrient in soil can also cause stresses. Out of the major physiological constraints imposed by various abiotic stresses, drought and heat alone can cause more than 50\% yield loss in chickpea. Among the primary factors of crop production that determine productivity, moisture availability is the most important. Soil moisture stress has a great impact on soil temperature, plant nutrient availability, activities as well as survivility of soil flora and fauna, root growth and activity. In case of severe stress there is disruption of normal cell metabolism which is accompanied by break down of proteins and carbohydrates causing an increase in the concentration of sugars, leaf phosphorous, and nitrogen migrate from older leaves to the stem. In addition to this, phosphate fertilization of chickpea promotes growth, nodulation, and enhances yield, grain quality, regulate the phosphate synthesis, govern physio-bio-chemical processes and also help in root enlargement, nodule production and thereby increase nitrogen fixation 
(Siag et al.1990). Although phosphorous availability is governed by a number of factors, moisture regime and phosphorous status of the soil exerts over helping influence.Since information on water management in chickpea under varying levels of phosphorous are very meager and fragmented. The present experiment were planned to find out effect of irrigation and phosphorous on yield contributing characters and yield of chickpea.

\section{Materials and methods}

The present experiment entitled "Effect of irrigation and phosphorous levels on yield attributes and yield of chickpea (Cicer arietinum L.)" was conducted at Agronomy Research Farm of Narendra Deva University of Agriculture \& technology, Kumarganj, Faizabad, during two consecutive rabi season of 2004-05 and 2005-06. The Experiment was laid out in split plot design having four irrigation levels viz. $\mathrm{I}_{0^{-}}$un-irrigated, $\mathrm{I}_{1^{-}}$ irrigation at branching stage, $\mathrm{I}_{2^{-}}$Irrigation at pod formation stage, $\mathrm{I}_{3^{-}}$irrigation at branching at pod formation stage, as main plot treatments, and four phosphorous levels viz. $\mathrm{P}_{0^{-}} 0 \mathrm{~kg} \mathrm{P}_{2} \mathrm{O}_{5} / \mathrm{ha}, \mathrm{P}_{1^{-}} 20 \mathrm{~kg}$

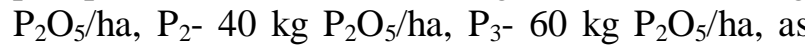
sub plot treatments. Total 16 treatment combinations replicated four times. The soil of the experimental site was silty loam in texture with low organic carbon $(0.38 \%$ and $0.38 \%)$ and nitrogen (179.8 and $188.6 \mathrm{~kg} / \mathrm{ha})$, medium in phosphorous (14.8 and $15.6 \mathrm{~kg} / \mathrm{ha}$ ) and potassium (264.6 and $255.4 \mathrm{~kg} / \mathrm{ha}$ ). There was 42.26 and $6.8 \mathrm{~mm}$ rainfall during the respective seasons. The observations on plant height, number of branches per plant, number of nodules per plant, number of pods per plant, number of grains per pod, and grain yield taken at the time of harvest. The data collected from the experiment were subjected to statistical analysis with the procedure of Split Plot Design as suggested by Gomez and Gomez (1984).

\section{Results and Discussion}

The results obtain from the experiment presented in the Table-1. The plant height of chickpea increased significantly with various irrigation schedule given at different critical stages of growth over control. The tallest plant height $(53.52$ and $52.12 \mathrm{~cm})$ was recorded in the treatment having irrigation at two stages i.e. one each at branching and pod formation stage $\left(\mathrm{I}_{3}\right)$, which significantly superior over the other treatments. Similar trend also observed in second year of experiment. The maximum plant was recorded with highest dose of phosphorous (60 $\mathrm{kg} \mathrm{P}_{2} \mathrm{O}_{5} / \mathrm{ha}$ ) as compared to rest of the treatments

Table 1. Effect of irrigation and phosphorous levels on yield attributes and yields of chickpea

\begin{tabular}{|c|c|c|c|c|c|c|c|c|c|c|c|c|}
\hline \multirow[t]{2}{*}{ Treatments } & \multicolumn{2}{|c|}{$\begin{array}{l}\text { Plant height } \\
\text { (cm) }\end{array}$} & \multicolumn{2}{|c|}{$\begin{array}{l}\text { Number of } \\
\text { branches per } \\
\text { plant }\end{array}$} & \multicolumn{2}{|c|}{$\begin{array}{l}\text { Number of } \\
\text { nodules per } \\
\text { plants }\end{array}$} & \multicolumn{2}{|c|}{$\begin{array}{l}\text { Number of } \\
\text { pods per } \\
\text { plant }\end{array}$} & \multicolumn{2}{|c|}{$\begin{array}{l}\text { Number of } \\
\text { grains per } \\
\text { pod }\end{array}$} & \multicolumn{2}{|c|}{$\begin{array}{l}\text { Grain yield } \\
(\mathrm{q} / \mathrm{ha})\end{array}$} \\
\hline & $\begin{array}{l}2004 \\
-05 \\
\end{array}$ & $\begin{array}{l}2005 \\
-06\end{array}$ & $\begin{array}{l}2004 \\
-05\end{array}$ & $\begin{array}{l}2005 \\
-06\end{array}$ & $\begin{array}{l}2004 \\
-05\end{array}$ & $\begin{array}{l}2005 \\
-06\end{array}$ & $\begin{array}{l}2004 \\
-05\end{array}$ & $\begin{array}{l}2005 \\
-06\end{array}$ & $\begin{array}{l}2004 \\
-05\end{array}$ & $\begin{array}{l}2005 \\
-06 \\
\end{array}$ & $\begin{array}{l}2004 \\
-05\end{array}$ & $\begin{array}{l}2005 \\
-06\end{array}$ \\
\hline \multicolumn{13}{|c|}{ Irrigation level } \\
\hline$I_{0}$ & 46.01 & 44.35 & 13.32 & 12.94 & 8.90 & 8.47 & 30.26 & 29.07 & 1.50 & 1.49 & 16.86 & 15.73 \\
\hline $\mathrm{I}_{1}$ & 49.01 & 47.10 & 15.00 & 14.78 & 10.23 & 10.15 & 35.06 & 33.56 & 1.65 & 1.71 & 19.80 & 18.22 \\
\hline $\mathrm{I}_{2}$ & 48.01 & 46.23 & 14.11 & 13.63 & 9.79 & 9.13 & 32.12 & 31.17 & 1.59 & 1.62 & 18.73 & 18.23 \\
\hline $\mathrm{I}_{3}$ & 53.52 & 52.12 & 17.72 & 17.30 & 11.46 & 10.30 & 38.55 & 37.05 & 1.75 & 1.74 & 21.94 & 20.88 \\
\hline SEm \pm & 1.37 & 1.33 & 0.41 & 0.40 & 0.27 & 0.27 & 1.10 & 1.07 & 0.05 & 0.05 & 0.43 & 0.46 \\
\hline $\mathrm{CD}($ at $5 \%)$ & 4.41 & 4.25 & 1. & 1.30 & 0.8 & 0.87 & 3.53 & 3.44 & 0.16 & 0.16 & 1.4 & 1.49 \\
\hline \multicolumn{13}{|c|}{ Phosphorous levels } \\
\hline $\mathrm{P}_{0}$ & 45.67 & 43.70 & 13.06 & 12.96 & 8.92 & 8.51 & 25.00 & 23.64 & 1.45 & 1.55 & 14.70 & 13.80 \\
\hline $\mathrm{P}_{1}$ & 48.55 & 46.75 & 14.70 & 14.33 & 10.05 & 9.75 & 31.60 & 31.05 & 1.61 & 1.60 & 18.98 & 16.62 \\
\hline $\mathrm{P}_{2}$ & 50.40 & 48.67 & 15.74 & 15.23 & 10.39 & 9.87 & 37.06 & 35.61 & 1.67 & 1.65 & 21.01 & 19.75 \\
\hline $\mathrm{P}_{3}$ & 51.92 & 50.68 & 16.65 & 16.13 & 10.04 & 10.92 & 41.51 & 40.01 & 1.77 & 1.78 & 22.64 & 21.75 \\
\hline SEm \pm & 1.21 & 1.17 & 0.36 & 0.35 & 0.24 & 0.23 & 1.07 & 1.05 & 0.05 & 0.05 & 0.34 & 0.43 \\
\hline $\mathrm{CD}$ (at 5\%) & 3.49 & 3.37 & 1.04 & 1.02 & 0.70 & 0.68 & 3.10 & 3.02 & 0.14 & 0.14 & 1.08 & 1.23 \\
\hline
\end{tabular}


during both the year of experiment.The branches per plant recorded significantly higher under two irrigations $\left(\mathrm{I}_{2}\right)$ over the rest of the treatment. Same trend also observed in the next year of studies. The maximum number of branches per plant was recorded with the application of $60 \mathrm{~kg} \mathrm{P}_{2} \mathrm{O}_{5} / \mathrm{ha}\left(\mathrm{P}_{3}\right)$ which was at par with $\mathrm{P}_{2}$ and observed significantly superior over rest of the treatment during 2004-05 and 2005-06.The maximum numbers of nodules per plant was recorded with the application of two irrigations $\left(\mathrm{I}_{3}\right)$, which was significantly superior over rest of the irrigation treatments during both the years. Phosphorous at the rate of $60 \mathrm{~kg} / \mathrm{ka}$ $\mathrm{P}_{2} \mathrm{O}_{5}$ recorded significantly highest number of nodules per plant during both the years as compared to other treatments. The maximum number of pods per plants increased with increasing levels of irrigations. The maximum number of pods per plant was recorded with the application of two irrigations which was significantly superior over all the irrigation treatment during both the years. Significantly maximum number of pods per plant was associated with the application of $60 \mathrm{~kg} \mathrm{P}$ ${ }_{2} \mathrm{O}_{5} /$ ha during both the years. Similar trend was also observed in the case of number of grains per pod.The examination of data indicates that irrigation schedule at various critical stages of the growth had significant impact on grain yield of chickpea. The highest grain yield was obtained with two irrigations one each at branching and pod formation stage $\left(\mathrm{I}_{3}\right)$ which was significantly superior over rest of the treatments during both the years. The application of two irrigations $\left(\mathrm{I}_{3}\right)$ enhanced the crop yield by 30.13 and $32.73 \%$ over $\mathrm{I}_{0}, 17.13$ and $21.18 \%$ over $\mathrm{I}_{1}$, and 10.80 and $14.59 \%$ over $\mathrm{I}_{2}$ during 2004-05 and 2005-06 respectively. Phosphorous application also significantly influenced the grain yield of chickpea. The maximum grain yield (22.64 and $21.75 \mathrm{q} / \mathrm{ha})$ was found with application of $60 \mathrm{~kg} \mathrm{P}_{2} \mathrm{O}_{5} / \mathrm{ha}\left(\mathrm{P}_{3}\right)$ which was significantly superior over rest of the treatment during both the year.The results obtained are in the agreement with Singh \& Singh (1989), Joseph \& Verma (1994) and Meena et al. (2006).

\section{Conclusion}

The results summarized that, the application of two irrigations, one each at branching and pod formation stage alongwith $60 \mathrm{~kg} \mathrm{P}_{2} \mathrm{O}_{5} / \mathrm{ha}$ to be found best as compared to the rest of the treatment. hence may be recommended for chickpea crop grown by the farmers of eastern Uttar Pradesh.

\section{References}

Ali, M and Kumar, S. 2005. Chickpea (CicerarietinumL.) research in India, accomplishment and future strategies. Indian J. Agric. Sci. 75(3): 125-133.

Ali, M; Kumar, S. and Singh N.B. 2003. Chickpea research of India. Indian Institute of Pulse Research: 99-118.

Gomez, K.A. and Gomez, A.A. 1984. Statistical procedure for agricultural research. $2^{\text {nd }}$ John Willey and Sons, New York: 660.

Joseph, B. and Verma, S.C. 1994. Response of rainfed chickpea (Cicer arietinum L.) to Jalshakti incorporation, phosphorous and sulphar fertilization. Indian J. Agron. 39(2): 312-314.

Meena, L.R.; Singh, R.K. and Gautam, R.C. 2006. Effect of moisture conservation practices, phosphorous levels and bacterial inoculation on growth, yield and economics of chickpea Cicerarietinum L.). Legume Research. 29(1): 6872 .

Siag, R.K., Verma, B.L. and Sidhu B.S. 1990. Effect of irrigation regimes and phosphorous levels on yield and water use efficiency of chickpea. Indian J. of Pulse Res. $3(1): 31-35$

Singh, D.P. \& Singh, T.P. 1989. Response of gram to row spacing and phosphorous fertilization. Indian J. Agron. 33(1): 107-109. 